\title{
Prevention of Wildlife Trafficking and Poaching In Tanzania by Using Forensic Science Technological Approach
}

\author{
*Michael Mgimba \\ Department of Microbiology and Parasitology, Sokoine University of Agriculture, Tanzania
}

Submission: February 10, 2017; Published: February 27, 2017

*Corresponding author: Michael Mgimba, Department Of Microbiology And Parasitology, College Of Veterinary And Medical Sciences, Sokoine University Of Agriculture, P.O. Box 3000 SUA, Chuo Kikuu Morogoro, Tanzania, Tel: +255753284111; Email: michaelmgimba72@gmail.com

Abstract

Poaching is the act of illegal hunting of preserved and endangered wild species in the highly conserved areas and national parks. This trade is much rising in SADC countries due to demand of raw materials for industries in Asian continent. These countries make more demand of ivory and live animals for business. Forensic science can be the only way to help banning of this business all over Africa.

\section{Introduction}

Tanzania is located on the eastern coast of Africa. It lies between 1 degree and 11 degrees south of the Equator. It is bordered by Uganda and Kenya to the north. Its southern neighbors comprise of Zambia, Mozambique and Malawi. Burundi, Zaire (Democratic Republic of Congo) and Rwanda border it in the West. It covers a massive area of slightly over $900,000,000 \mathrm{~km}$. sq. including the Island of Zanzibar, Mafia and Pemba. Tanzania is having a great wealth in Wild animal species, fish and natural resources. These animal species are confined in natural geographic barriers called national parks and conservation authorities such as Serengeti, Tarangire, Mikumi, Manyara, Ngorongoro, Selous, Kilimanjaro, Momela, Ruaha etc [1].

\section{How does Tanzania affected by pouching and wildlife trafficking?}

A new report shows that poaching has reduced Tanzania's elephant numbers by 60 percent during the past five years, from almost 110,000 to just over 43,000 . This scenario is due to increasing demand on elephants tusks by developed countries for industrial raw materials, therefore pouching is a big business in the country and is a threat by almost $70 \%$, and this is a historical perspective since colonialism.

I. Pouching: Is an illegal hunting of wild animal species for the aim of obtaining valuable raw materials for industrial and prestigious purposes. Asian countries marks the highly demand of elephant tusks for production of raw materials for industries and gallery utensils for prestigious purposes [2].
What could be the real approach for prevention of poaching and wildlife trafficking in Tanzania?

Forensic science would be the answer for this problem by using forensic DNA analysis in investigation of crimes such as animal cruelty, poaching, illegal collection and trade of flora and wildlife trafficking. Technological advances made in the field of human forensic genetics which has allowed transfer of methods and applications to the field of animal forensic, though this has been inefficiently with a gradual drawbacks than with human forensic genetics for a number of reasons, which includes:

i. Unlike human forensic genetics, forensic DNA analysis for animal protection suffers very low genetic markers.

ii. Lack of validity in the animal forensic analysis, this is due to the reason that most of genetists were dealing with human, genetics for almost the whole life history since the discovery of DNA delt with human by almost high percentage, hence invalid markers for animals during DNA analysis. Poverty in most of African societies, this may be the seducing factor to involve and engaging African citizens in this dirty business of poaching and wildlife trafficking as by having only one tusk it worth about $\$ 2000$, therefore most of young men involve in this business. Neglegence to crimes involving animals compared to those of humans being. Thus, with the exception of a few endangered animal species like elephants, giraffes etc.

iii. Government policy, finally, there would be a policy that govern the illegal business by introducing Acts and contracts 
with those countries in high demand of the ivory, tusks and other endangered species bioproducts for industrial purposes [3].

The application and involving of forensic DNA analysis techniques in this war is obvious potential to the country and the world in general. During analysis of the evidence from endangered species there should be maintenance of chain of custody from the time of collection of the evidence, processing until submission to the court of law for further proceedings, though trustfulness and ethical manners are to be followed by every personnel in the authority.

\section{Biological evidence}

When investigating crimes against animals or protected endangered species varies but it depends on the type, scenario, age, sex of animal surrendered for further DNA analysis. The samples may include tissue, hair, feathers, tusks, claws, tanned leather, bile crystals, scales, shells, processed animal parts and derivatives within Traditional Chinese Medicines (TCMs), and objects made out of animal parts such as hankies, shawls, idols and handbags etc.

\section{Forensic applications}

Studies to date have reported diverse types of forensic investigations including poaching, illegal trade, detection of protected and endangered species within East Africa and mainly Tanzania [4].

\section{How is it done?}

DNA Maps can be constructed using feaces (dungs) of endangered species like elephants and rhinos, logically these animals they defecate very large balls of feaces, so they sloughs off some epithelial cells from their digestive track which will be found in the feaces and every animal will have its DNA markers in its dung. During preparing of the DNA maps each of them will have its own identity and this will help to construct individual DNA map.DNA maps will be used to determine the seized ivories in foreign countries in high demand of ivory hence recognition of their originality by their unique finger printing. Many scientists, institutions, NGO's and Authorities has made their efforts for conducting various researches for the problem especially in Tanzania by using DNA analysis. Zoologist Sam Wasser, a research professor at the University of Washington, spent years extracting DNA from elephant dung and tissue across the African continent. He used it to draw a map that shows the genetic signature of each major population, which is a kind of a bar code for elephants [5].

Then he started taking DNA from illegal ivory seized around the world so he could match the ivory's bar code to the place and population it came from. He discovered the major two places affected by the business which were central Africa and East Africa especially Tanzania. Generally poachers are very tactical as it's not possible for them to be caught in the act, but the only thing is to track their routes during shipment to highest selling markets of ivory in Asia. The governments should impose laws and regulations by signing contracts with those countries in high demand of ivory worldwide at least to reduce the intensity of mortality rate of elephants and rhinos in Tanzania. Some countries such as China, Malaysia and others with high demand of ivory are to impose rules for banning this business too, and agree to sign the imposed rules by the Tanzania Government. One thing to support this war against wildlife trafficking and poaching in Tanzania is for stake holders worldwide to initiate various projects by funding young scientists from Sokoine Univesity of Agriculture, Morogoro Tanzania with Biotechnology and Laboratory sciences advanced skills to conduct researches by helping their country.

\#Animals has rights to live, stop wildlife trafficking and poaching in Tanzania\#

\section{References}

1. Center for Conservation Biology. Department of Biology, University of Washington, USA.

2. R Amin, K Thomas, RH Emslie, TJ Foose, N Van Strien (2006) An overview of the conservation status of and threats to rhinoceros species in the wild. International Zoo Yearbook 40(1): 96-117.

3. International Zoo Yearbook (1973) Convention on International Trade in Endangered Species (CITES) of Wild Fauna and Flora. USA.

4. World Society for the Protection of Animals (2007) WSPA and Animal Planet take on the illegal wildlife trade.

5. Rob Ogden, Nick Dawnay, Ross McEwing (2009) Wildlife DNA forensics-bridging the gap between conservation genetics and law enforcement. Endang Species Res 9: 179-195.

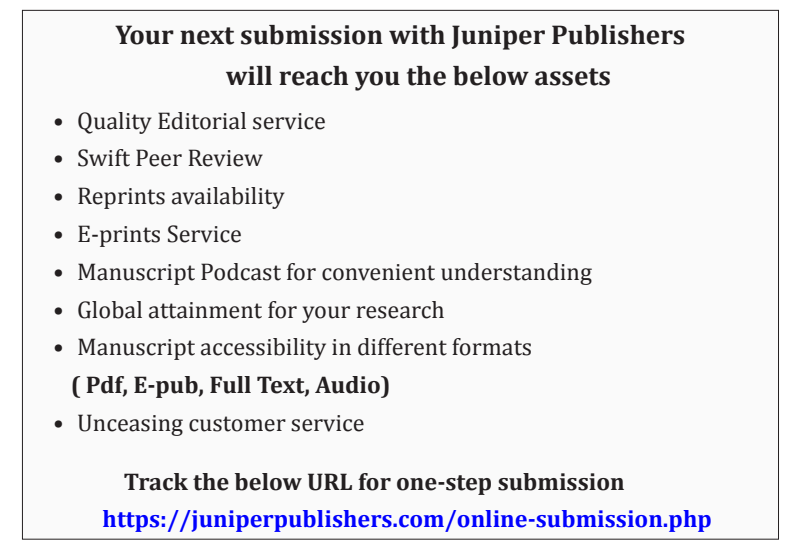

